\title{
SOCIO-ENVIRONMENTAL VULNERABILITY OF WATER IN THE ESTUARY OF THE METROPOLITAN REGION OF SANTOS (BRAZIL)
}

\author{
Fernando L.C. Martins" ${ }^{1}$, Fabio Giordano ${ }^{2}$, Walter Barrella ${ }^{2,3}$ \\ ${ }^{1}$ Sanitation Company of the State of São Paulo - SABESP, Santos, Brazil \\ ${ }^{2}$ Department of Biology, Santa Cecilia University - UNISANTA, Santos, Brazil \\ ${ }^{3}$ Universidade Paulista - UNIP, Instituto de Ciências da Saúde (ICS) Sorocaba - SP, Brazil
}

Manuscript received: October 31, 2020

Revised version: May 7, 2021

\begin{abstract}
Martins F.L.C., Giordano F., BarRella W., 2021. Socio-environmental vulnerability of water in the estuary of the metropolitan region of Santos (Brazil). Quaestiones Geographicae 40(4), Bogucki Wydawnictwo Naukowe, Poznań, pp. 113-125. 1 fig., 8 tables.

ABSTRACT: Santos and São Vicente Estuarine Complex (SSEC) is a densely populated coastal area that houses the main port in Latin America and the most prominent Brazilian industrial complex. Irregular occupations in preservation areas result in a disorderly increase in population, with negative social and environmental impacts. We evaluated the average annual growth of 74 slums occurring in this area and variations in water quality from 2005 to 2018 . We monitor the growth of the occupied areas and estimate their respective populations. The average annual population growth was over $6 \%$ per year (p.a.). Invasions of new areas and verticalisation of already occupied areas represent $85 \%$ of the growth seen. The monthly polluting loads exceeded 450 tonnes or 2,086,000 $\mathrm{m}^{3}$, compromising the waters and local and regional public health. We strongly recommend re-urbanising the area using the resource savings caused by water loss to reduce the risks of ecosystem degradation, damage to health and disease spread.
\end{abstract}

KEYwORDS: population growth, slums, shantytown, coastal zone, urban slums, urban vulnerability

Corresponding author: Walter Barrella, Universidade Paulista, Ciências Biológicas, Ave Independência, 210 Sorocaba, 18087-101, Brazil; e-mail: walterbarrella@gmail.com

\section{Introduction}

According to the United Nations, the world population growth rate will be more pronounced in the coming decades, with an increase of 2.5-3 billion people by 2050, and with that, there will be an increase in the need for water, sanitation and hygiene (Leridon 2020). This phenomenon will boost vulnerability in socio-environmental, urban, economic and political spheres (Cutter et al. 2003). The United Nations Department of Public Information Report showed that in 2012, approximately 828 million people lived in slums with a growth rate of $6 \%$ per year (p.a.), and by 2020 it should reach 889 million in the urban migration process (UN 2012 and 2013). Coastal zones are more densely populated than inland areas and exhibit higher rates of population growth and urbanisation. The development of coastal areas has increased considerably in recent decades, producing socioeconomic changes and generating high pressure on ecosystems due to the exploitation of natural resources and pollution. Land use and urbanisation are also related to

\section{sciendo}




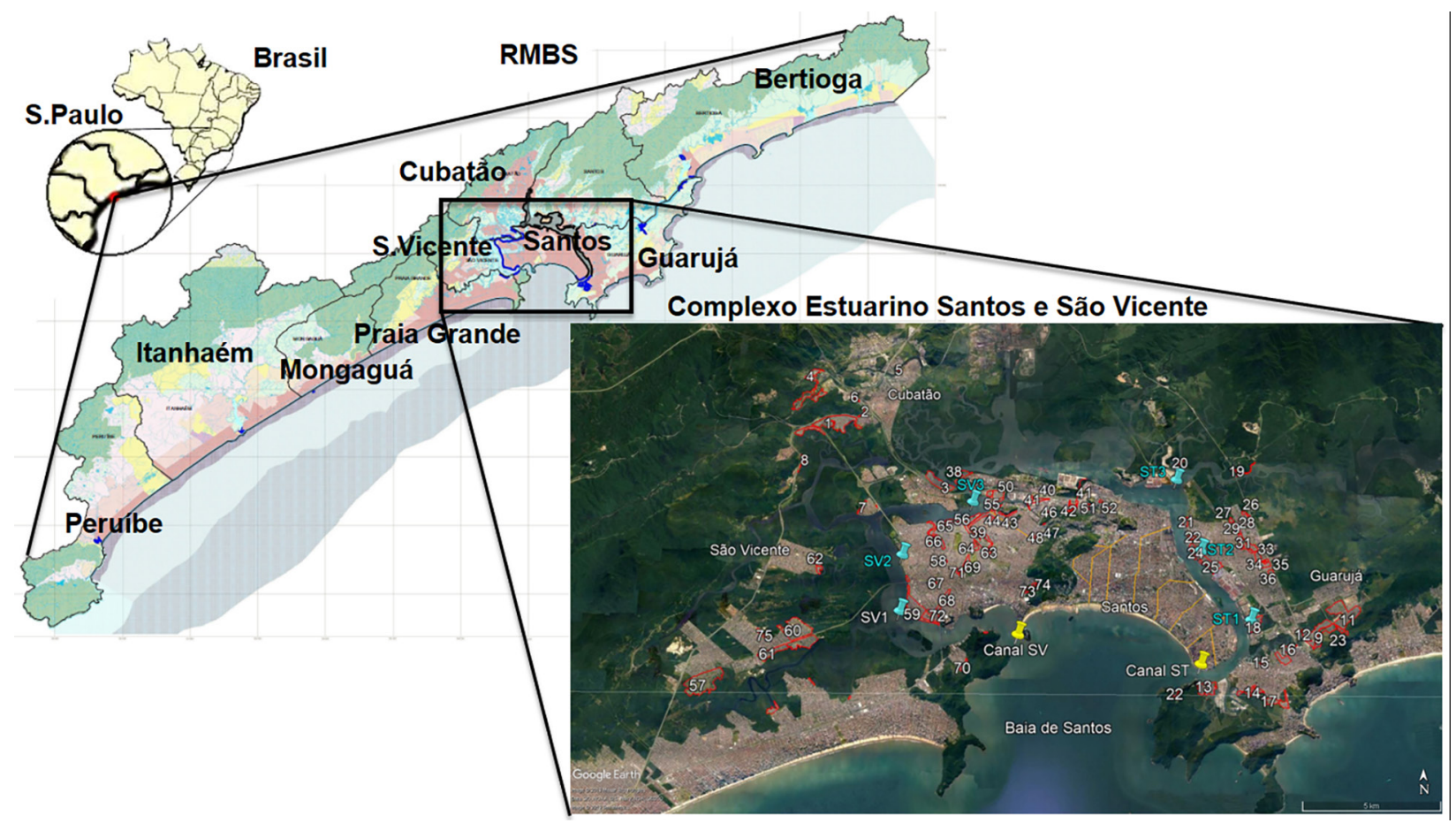

Fig. 1. Location of the SSEC area. Red polygons limit areas of high vulnerability; cyan markers show localities of six water sample collection points (3 in Santos (ST1-3) and 3 in São Vicente (SV1-3)); orange lines represent artificial drainage canals; yellow markers define natural channels entry to the estuary in the municipalities of

Santos (ST) and São Vicente (SV).

Source: Google Earth, adapted by the author, 2018.

SSEC - Santos and São Vicente Estuarine Complex.

increasing population exposure and vulnerability along the coasts, especially in developing countries (Small, Nicholls 2003; Balk et al. 2009; Kron 2013; Neumann et al. 2015). In these zones, we can find vulnerable nuclei (VN), subnormal agglomerations, precarious settlements and slums, characterised by populations with low incomes and lack of access to safe drinking water, sanitation, and public housing and health policies, who live in non-conforming housing (NH) (IBGE 2010; SAO PAULO 2010; AGEM 2015; UN-BR 2018).

Port, industrial and tourist activities drive the Baixada Santista Metropolitan Region (BSMR) located in the Santos and São Vicente Estuarine Complex (SSEC) and induce invasions in flooded areas, where we find the largest slum on stilts in Brazil (Fabiano, Muniz 2010; Sampaio et al. 2011). The main actors behind this problem are the municipal governments who do not draw up adequate master plans for popular low-income occupations and parallel power organisations that rent out these irregular areas for the occupation of precarious housing. Housing changes and urban regularisation imply better sanitary conditions since the houses are now supplied by a regular water and sewage distribution system, in addition to allowing other essential services such as regular garbage collection. The improvement is a natural result of the replacement of irregular housing. The water quality of local watercourses automatically improves its indicators from the moment the raw sewage stops being deposited. Sewage discharge, inadequate waste disposal and port accidents compromise the quality of water and sediments. We analysed the population growth of $\mathrm{VN}$ in the SSEC and verified the water quality changes between 2005 and 2018.

\section{Methods}

\section{Study area}

The BSMR, with 1,848,654 inhabitants, is located on the south-eastern Brazilian coast, $2,428,737 \mathrm{~km}{ }^{2}$ characterised by $65 \mathrm{~km}$ of continuous coastline. Bordered by the Serra do Mar cliffs, with remnants of the Atlantic Forest, there 
is a great diversity of ecosystems such as mangroves, estuaries, islands, sandbanks, coves, dunes, beaches and rocky shores. Most of these are protected through conservation units or other types of protected areas by law (IBGE 2018). The SSEC have several meandered channels that receive fluvial discharges that flow into Santos Bay through two channels (Fig. 1). On the eastern side, the Santos channel, with a width of $360 \mathrm{~m}$ and an average depth of $14 \mathrm{~m}$, is maintained by dredging to navigate great ships. The São Vicente channel is on the west side, with an average depth of $8 \mathrm{~m}$ and a width of $585 \mathrm{~m}$, narrowing to $185 \mathrm{~m}$ under the 'Pensil' bridge (Sampaio et al. 2011). Sewage, waste and emerging pollutants (salts and nutrients) harm public health in the estuary (CETESB 2017).

\section{Housing and territorial data}

We collect housing and population data from formal and informal areas. Each VN's coordinates and territorial space (Fig. 1) were also obtained and complemented by using Google Earth software (AGEM 2015; IBGE 2018; Annex A; Annex B). The study area group (SAG) brings together the number of households, populations and territories in formal and informal areas of Santos, São Vicente, Cubatão and Guarujá municipalities.

We calculate geometric annual growth rate (GAGR) by applying equation (Eq.) (1) (RIPSA 2018):

$$
\text { GAGR }=\left[\sqrt[n]{\frac{(P n+1)}{P n}}-1\right] \times 100
$$

where

- Pn+1: future population (inhabitants, households)

- Pn: current population (inhabitants, households)

- GAGR: geometric annual growth rate (\% p.a.)

- $n$ : number of years (years)

\section{Growth clusters}

We calculated the GAGR for the number of non-compliant houses and the areas of occupancy of the VN $\left(\mathrm{GAGR}_{\mathrm{NH}}\right.$ and GAGR m²) so that it was possible to identify four types of growth, as shown
Table 1. Housing growth clusters $\left(\mathrm{GAGR}_{\mathrm{NH}}\right)$ and territorial $\left(\mathrm{GAGR}_{\mathrm{m}}{ }^{2}\right)$.

\begin{tabular}{|c|c|c|l|}
\hline \multirow{2}{*}{ Type } & \multicolumn{3}{|c|}{ Growth clusters } \\
\cline { 2 - 4 } & $\begin{array}{c}\text { Dwellings } \\
\left(\mathrm{GAGR}_{\mathrm{NH}}\right)\end{array}$ & $\begin{array}{c}\text { Territorial } \\
\left(\mathrm{GAGR}_{\mathrm{m}}{ }^{2}\right)\end{array}$ & \multicolumn{1}{|c|}{ Features } \\
\hline 1 & + & + & $\begin{array}{l}\text { Invasions and rein- } \\
\text { vasions }\end{array}$ \\
\hline 2 & + & - & $\begin{array}{l}\text { Verticalisation and } \\
\text { densification }\end{array}$ \\
\hline 3 & - & + & $\begin{array}{l}\text { Demobilisation and } \\
\text { pre-invasion }\end{array}$ \\
\hline 4 & - & - & Demobilisation \\
\hline
\end{tabular}

GAGR - geometric annual growth rate; $\mathrm{GAGR}_{\mathrm{NH}}$ geometric rate of annual growth of the population in non-conforming housing.

in Table 1. The type 1 cluster, with the increase in the number of houses and occupied areas, represents irregular and recurring occupations. Type 2, shows an increase in accommodation and a decrease in the area. The type 3 group indicates the preparation of a new irregular occupation. Type 4 represents the government's relocation actions but is not necessarily associated with the inspection and recovery of degraded areas.

\section{Water quality}

Based on the data available in the National Sanitation Information System (NSIS), we calculate the sewage flow rate $(\mathrm{Q})$ generated by human dwellings (HD) as $80 \%$ of water (Von Sperling 2014) according to Eq. (2), and the released pollutant load (PL) in the body of water according to equation (3):

$$
\begin{gathered}
(\mathrm{IN} 053 \times \mathrm{IN} 051 \times \mathrm{NH} \times 0.8)=\mathrm{Q} \\
(\mathrm{IN} 053 \times \mathrm{IN} 051 \times \mathrm{NH} \times 0.8 \times \mathrm{k})=\mathrm{Q}
\end{gathered}
$$

where

- Q: sewage flow per HD $-\mathrm{m}^{3} \cdot$ year $^{-1}$,

- PL: polluting load $-\mathrm{m}^{3} \cdot$ year $^{-1}$,

- IN051: loss ratio per house $\mathrm{m}^{3} \cdot$ house $^{-1} \cdot$ year $^{-1}$,

- IN053: average water consumption per dwelling $-\mathrm{m}^{3} \cdot$ dwelling $^{-1} \cdot$ year $^{-1}$,

- NH: non-conforming housing - units $\cdot y^{-1}{ }^{-1}$,

- 0.8: contribution factor of sewage generation by housing,

- k: 54 g per inhabitant daily (value used in this study). 
Table 2. Identification of the channels of Santos and São Vicente and collection points in SSEC.

\begin{tabular}{|c|c|c|c|c|}
\hline \multirow{2}{*}{ County } & \multicolumn{2}{|c|}{ Coordinates (UTM) } & $\begin{array}{c}\text { Distance from mouth } \\
\text { of Santos }(\mathrm{km})\end{array}$ & $\begin{array}{c}\text { Distance from mouth } \\
\text { of São Vicente }(\mathrm{km})\end{array}$ \\
\hline st1 & $369,107 \mathrm{E}$ & $7,347,706 \mathrm{~S}$ & 3.1 & 31.9 \\
\hline st2 & $367,145 \mathrm{E}$ & $7,350,411 \mathrm{~S}$ & 6.2 & 31.8 \\
\hline st3 & $366,363 \mathrm{E}$ & $7,353,172 \mathrm{~S}$ & 9.0 & 26.0 \\
\hline sv3 & $355,832 \mathrm{E}$ & $7,347,793 \mathrm{~S}$ & 21.4 & 13.6 \\
\hline sv2 & $355,575 \mathrm{E}$ & $7,349,873 \mathrm{~S}$ & 27.3 & 7.7 \\
\hline sv1 & $358,418 \mathrm{E}$ & $7,352,163 \mathrm{~S}$ & 29.7 & 5.3 \\
\hline
\end{tabular}

Source: Google Earth, adapted by the author, 2018.

Sewage flow and polluting load (mainly phosphate) information was related to the estuarine water quality in six points (Fig. 1 and Table 2), obtained in 2011 and 2017 (CETESB). We compare results to the limits established in the Brazilian Law 357 CONAMA Resolution (BRAZIL 2005).

\section{Results}

\section{Growth of formal and informal areas}

From 2005 to 2018, in urbanised areas, SAG municipalities presented a GAGR of $0.77 \%$ p.a., lower than the BSMR growth rate, which was $1.28 \%$ p.a. In the same period, $74 \mathrm{VN}$ informal areas presented a geometric rate of annual growth of the population in non-conforming housing $\left(\mathrm{GAGR}_{\mathrm{NH}}\right)$ of $5.60 \%$ p.a., below the BSMR growth rate of $6.07 \%$ p.a. in $525 \mathrm{VN}$ (Table 3).

\section{Growth clusters}

VN growth clusters shown in Table 4 demonstrate a lower growth outlook for $\mathrm{GAGR}_{\mathrm{NH}}$ than that for RMBS. The positive double growth for dwellings and occupied areas (type 1) shows intense invasion dynamics, together with the densification and verticalisation process expressed in type 2 growth, which presented a GAGR ${ }_{\mathrm{NH}}$ of $7.25 \%$ p.a.; moreover, this presented a reduction of the occupied area of $-1.94 \%$ p.a., representing $85 \%$ of the VN present in SSEC. The VN's demobilisation process, represented by cluster type 3 with a GAGR $\mathrm{NH}_{\mathrm{NH}}$ of $-3.01 \%$ p.a. and GAGRm ${ }^{2}$ of

Table 4. Housing and territorial growth clusters.

\begin{tabular}{|c|c|c|c|c|c|}
\hline Type & NH & $\mathrm{m}^{2}$ & Qty VN & $\begin{array}{c}\mathrm{GAGR}_{\mathrm{NH}} \\
(\% \text { p.a. })\end{array}$ & $\begin{array}{c}\mathrm{GAGR}_{\mathrm{m}}^{2} \\
(\% \text { p.a. })\end{array}$ \\
\hline 1 & + & + & 51 & 8.94 & 5.73 \\
\hline 2 & + & - & 12 & 7.25 & -1.94 \\
\hline 3 & - & + & 3 & -3.01 & 1.47 \\
\hline 4 & - & - & 8 & -4.54 & -8.48 \\
\hline \multicolumn{2}{|c|}{ SAG } & 74 & \multicolumn{2}{|c|}{5.60} & \multicolumn{2}{|c|}{0.09} \\
\hline \multicolumn{2}{|c|}{ BSMR } & 599 & \multicolumn{2}{|c|}{6.07} & \multicolumn{2}{c|}{$(*)$} \\
\hline
\end{tabular}

BSMR - Baixada Santista Metropolitan Region; GAGR geometric annual growth rate; $\mathrm{GAGR}_{\mathrm{NH}}$ - geometric rate of annual growth of the population in non-conforming housing; $\mathrm{NH}$ - non-conforming housing; p.a. - per year; SAG - study area group; VN - vulnerable nuclei.

Source: AGEM (2015); Annex A, adapted by the author, 2018.

$\left(^{*}\right)$ not available.

Table 3. Formal and non-conforming population (NH) between 2005 and 2018 in SAG municipalities.

\begin{tabular}{|l|c|c|c|c|c|c|c|c|}
\hline & \multicolumn{3}{|c|}{ Population (residents) } & \multicolumn{2}{c|}{ GAGR (\% p.a.) } & $\begin{array}{c}\text { NH } \\
\text { (AGEM) }\end{array}$ & $\begin{array}{c}\text { NH } \\
\text { (SABESP) }\end{array}$ & $\begin{array}{c}\text { GAGR }_{\text {NH }} \\
\text { (\% p.a.) }\end{array}$ \\
\cline { 2 - 10 } & 2005 & 2014 & 2018 & $2005 / 2018$ & $2005 / 2014$ & 2005 & 2018 & $2005 / 2018$ \\
\hline Santos & 418,610 & 423,779 & 432,957 & 0.26 & 0.14 & 8,018 & 15,732 & 5.32 \\
\hline Cubatão & 113,271 & 123,785 & 129,760 & 1.05 & 0.99 & 8,620 & 2,935 & -7.95 \\
\hline São Vicente & 317,459 & 346,492 & 363,173 & 1.04 & 0.98 & 8,992 & 29,079 & 9.45 \\
\hline Guarujá & 276,945 & 303,397 & 318,107 & 1.07 & 1.02 & 19,300 & 39,345 & 5.63 \\
\hline SAG & $1,126,285$ & $1,197,501$ & $1,243,997$ & 0.77 & 0.68 & 30,581 & 62,090 & 5.60 \\
\hline BSMR & $1,567,581$ & $1,750,990$ & $1,848,654$ & 1.28 & 1.24 & 54,343 & 116,941 & 6.07 \\
\hline
\end{tabular}

GAGR - geometric annual growth rate; $\mathrm{GAGR}_{\mathrm{NH}}$ - geometric rate of annual growth of the population in non-conforming housing; NH - non-conforming housing; p.a. - per year; SAG - study area group; BSMR- Baixada Santista Metropolitan Region.

Source: IBGE 2018. 
$1.47 \%$ p.a., shows demobilisation and new areas in preparation for invasion. Cluster type 4, with a GAGR $_{\mathrm{NH}}-4.54 \%$ p.a. and $\mathrm{GAGR}_{\mathrm{m}}{ }^{2}-8.48 \%$ p.a., which, in addition to cluster type 3, represents $15 \%$ of the sampling plan, emphasises the disproportion between invasion and demobilisation/ enforcement actions.

\section{SSEC water quality and Santos Bay beaches}

Table 5 shows VN units that release sewage and influences water quality on monitoring points.

Using the concept of SSEC average water renewal time, according to Leitão and Mateus (2008), the Santos Channel (with a width of $360 \mathrm{~m}$ and a depth of $14 \mathrm{~m}$ ) and the São Vicente channel (with a width of $585 \mathrm{~m}$ and a depth of $8 \mathrm{~m}$ ) are subject to a hydrodynamic regime of the seas in periods of 6 hours. According to Sampaio et al. (2011), the channels' velocities vary between $0 \mathrm{~m} \cdot \mathrm{s}^{-1}$ and $0.5 \mathrm{~m} \cdot \mathrm{s}^{-1}$, and within SSEC currents, around $0.1 \mathrm{~m} \cdot \mathrm{s}^{-1}$ (Harari et al. 2007). In terms of water renewal flow under the influence of the tidal regime, the estimated range is $6 \mathrm{~km}$ and gives worse results at points sv3 and st3. The st3 point $9 \mathrm{~km}$ distant from the Santos channel is influenced by ship traffic in the Santos estuary channel, while the sv3 point does not receive large draft vessels. The average flow through the Santos channel is approximately $1,260 \mathrm{~m}^{3} \cdot \mathrm{s}^{-1}$, and the average flow through the São Vicente channel is $1,170 \mathrm{~m}^{3} \cdot \mathrm{s}^{-1}$. Table 6 presents the flow and polluting load of sewage discharged into water bodies in 2005 and 2018. The SAG received 451 tonnes $\cdot$ month $^{-1}$ of pollutants in 2018, much higher than 137 tonnes $\cdot$ month $^{-1}$ in 2011.

Table 7 shows the non-conforming occurrences in water quality parameters recommended by Brazilian environmental legislation CONAMA 357 (BRAZIL 2005; CETESB 2011; Campuzano et al. 2013; CETESB 2017). During 2011, we verified 42 occurrences of non-compliance with quality standards, while in 2017 the number of occurrences rose to 56, with several new occurrences in the São Vicente channel, which receives increasing loads of sewage from the northwest of Santos-São Vicente Island.

Table 5. Number of VNs in growth clusters, housing and territorial growth rates correlated with collection points.

\begin{tabular}{|l|c|c|c|c|c|c|}
\hline \multicolumn{1}{|c|}{ Cluster } & st1 & st2 & st3 & sv3 & sv2 & sv1 \\
\hline $1(+/+)$ & 14 & 2 & 8 & 16 & 3 & 8 \\
\hline $2(+/-)$ & 3 & 1 & 2 & 3 & 1 & 2 \\
\hline $3(-/+)$ & 2 & & & & 1 & 1 \\
\hline $4(-/-)$ & & & 3 & 6,888 & 3,308 & 5,758 \\
\hline NH $(2005)$ & 9,170 & 1,986 & 3,471 & 20,633 & 3,659 & 12,768 \\
\hline NH $(2018)$ & 15,172 & 4,846 & 5,012 & $8.81 \%$ p.a. & $0.78 \%$ p.a. & $6.32 \%$ p.a. \\
\hline GAGR & $3.95 \%$ p.a. & $7.10 \%$ p.a. & $2.87 \%$ p.a. & 11 & 2 & 5 \\
\hline New invasions & 4 & 0 & 4 & 11 & 2 \\
\hline
\end{tabular}

GAGR - geometric annual growth rate; $\mathrm{GAGR}_{\mathrm{NH}}$ - geometric rate of annual growth of the population in non-conforming housing; $\mathrm{NH}$ - non-conforming housing; p.a. - per year.

Source: Annex A, adapted by the author, 2018.

Table 6. Sewage flow and PL released in SSEC in 2005 and 2018.

\begin{tabular}{|c|c|c|c|c|c|c|c|c|c|}
\hline \multirow[t]{2}{*}{ County } & \multirow[t]{2}{*}{$\begin{array}{c}\text { IN051 } \\
\left(\mathrm{m}^{3} \cdot \mathrm{month}^{-1}\right)\end{array}$} & \multirow[t]{2}{*}{$\begin{array}{c}\text { IN053 } \\
\left(\mathrm{m}^{3} \cdot \mathrm{month}^{-1}\right)\end{array}$} & \multirow[t]{2}{*}{$\begin{array}{l}\text { Total } \\
\left.\cdot \text { month }^{-1}\right)\end{array}$} & \multicolumn{2}{|c|}{$\begin{array}{c}\text { HD } \\
\text { Number of irreg- } \\
\text { ular dwellings }\end{array}$} & \multicolumn{2}{|c|}{$\begin{array}{c}\text { Flow rate } \\
\left(\mathrm{m}^{3} \cdot \mathrm{month}^{-1}\right)\end{array}$} & \multicolumn{2}{|c|}{$\begin{array}{c}\text { Polluting load } \\
\left(\text { tonnes } \cdot \text { month }^{-1}\right)\end{array}$} \\
\hline & & & & 2005 & 2018 & 2005 & 2018 & 2005 & 2018 \\
\hline Cubatão & 17 & 20 & 37 & 5,674 & 2,935 & 90,784 & 86,876 & 20 & 19 \\
\hline Guarujá & 22 & 21 & 43 & 12,818 & 22,887 & 215,342 & 787,313 & 47 & 170 \\
\hline Santos & 8 & 45 & 53 & 3,826 & 7,275 & 137,736 & 308,460 & 30 & 67 \\
\hline São Vicente & 19 & 19 & 38 & 8,263 & 29,042 & 125,598 & 882,877 & 27 & 191 \\
\hline SAG & 16 & 26 & 42 & 30,581 & 62,090 & 636,085 & $2,086,224$ & 137 & 451 \\
\hline BSMR & 11 & 18 & 30 & 54,343 & 116,941 & 782,539 & $2,806,584$ & 169 & 606 \\
\hline
\end{tabular}

BSMR - Baixada Santista Metropolitan Region; PL - pollutant load; SAG - study area group.

Source: AGEM 2015; Sperling 2014; SNIS 2017; Annex B, adapted by the author, 2018. 
Table 7. Water quality measurements in non-conformity ("1" in yellow cells) with CONAMA 357.

\begin{tabular}{|l|c|c|c|c|c|c|c|c|c|c|c|c|c|}
\hline \multicolumn{1}{|c|}{ Year } & 2011 & 2011 & 2011 & 2011 & 2011 & 2011 & 2011 & 2011 & 2011 & 2011 & 2011 & 2011 & 2011 \\
\hline Station-Season & st1-S & st1-W & st2-S & st2-W & st3-S & st3-W & sv1-S & sv1-W & sv2-S & sv2-W & sv3-S & sv3-W & Total \\
\hline DO & & 1 & 1 & & 1 & 1 & & & 1 & 1 & 1 & 1 & 8 \\
\hline$P_{\text {TOTAL }}$ & & 1 & 1 & 1 & 1 & 1 & & 1 & & & 1 & 1 & 8 \\
\hline $\mathrm{NH}_{4}$ & 1 & & & & 1 & & & 1 & 1 & 1 & 1 & 1 & 7 \\
\hline TOC & & & & & 1 & 1 & 1 & & 1 & 1 & 1 & & 9 \\
\hline Ecotox. & & & & & & & & & & & 1 & & 1 \\
\hline Chlorophyll & 1 & 1 & 1 & 1 & 1 & & & 1 & & 1 & 1 & 1 & 9 \\
\hline Enterococcus & 3 & 3 & 4 & 3 & 5 & 3 & 1 & 3 & 3 & 4 & 6 & 4 & 42 \\
\hline Total 2011 & 2017 & 2017 & 2017 & 2017 & 2017 & 2017 & 2017 & 2017 & 2017 & 2017 & 2017 & 2017 & 2017 \\
\hline Year & & & & & 1 & & 1 & 1 & 1 & 1 & 1 & & 6 \\
\hline Station-Season & st1-S & st1-W & st2-S & st2-W & st3-S & st3-W & sv1-S & sv1-W & sv2-S & sv2-W & sv3-S & sv3-W & Total \\
\hline DO & 1 & 1 & 1 & 1 & 1 & 1 & 1 & 1 & 1 & 1 & 1 & 1 & 12 \\
\hline$P_{\text {Total }}$ & 1 & & 1 & & 1 & & & 1 & 1 & & 1 & 1 & 7 \\
\hline NH & 1 & 1 & 1 & 1 & 1 & 1 & 1 & & 1 & & 1 & 1 & 10 \\
\hline TOC & 1 & 1 & 1 & 1 & 1 & 1 & 1 & 1 & 1 & 1 & 1 & 1 & 12 \\
\hline Ecotox. & & & & & & & 1 & & 1 & & 1 & \\
\hline Chlorophyll & 1 & & 1 & & 1 & & 1 & & & & 1 & 1 & 6 \\
\hline Enterococcus & 5 & 3 & 5 & 3 & 6 & 3 & 6 & 4 & 6 & 3 & 7 & 5 & 56 \\
\hline Total 2017 & & & & & & & & & & & \\
\hline
\end{tabular}

$\mathrm{DO}$ - dissolved oxygen; $\mathrm{NH}_{4}$ - ammonia nitrogen; $\mathrm{P}_{\text {TOTAL }}$ - total phosphorus; $\mathrm{S}$ - summer; TOC - total organic carbon; W - winter; Ecotox. (Vibrio ficheri), Chlorophyll A, and Enterococcus.

Source: BRAZIL 2005; CETESB 2011; CETESB 2017.

\section{Water quality: Contributing rivers and Santos Bay (beaches)}

The deterioration of the bathing water also increased between 2005 and 2017 (Table 8), with the discharge of domestic sewage being the main factor for the low water quality of the beaches of Santos, São Vicente and Guarujá (CETESB 2017).

Table 8. Concentration of total coliforms in waterways urban effluent to beaches.

\begin{tabular}{|l|c|c|}
\hline \multicolumn{1}{|c|}{ County } & 2005 & 2017 \\
\hline Cubatão $\left(^{*}\right)$ & $10^{1}$ & $10^{1}$ \\
\hline Guarujá $\left(^{*}\right)$ & to & $10^{3}$ to $10^{5}$ \\
\hline Santos $\left(^{*}\right)$ & $10^{4}$ to $10^{5}$ & $10^{3}$ to $10^{6}$ \\
\hline São Vicente $\left(^{*}\right)$ & $10^{4}$ to $10^{5}$ & $10^{3}$ to $10^{6}$ \\
\hline Bertioga & $10^{3}$ & $10^{3}$ to $10^{4}$ \\
\hline Mongaguá & $10^{3}$ to $10^{4}$ & $10^{3}$ \\
\hline Itanhaém & $10^{3}$ to $10^{4}$ & $10^{3}$ \\
\hline Praia Grande & $10^{4}$ to $10^{5}$ & $10^{3}$ to $10^{6}$ \\
\hline Peruíbe & $10^{2}$ to $10^{3}$ & $10^{3}$ to $10^{4}$ \\
\hline
\end{tabular}

Source: CETESB 2017, adapted by the author, 2018. $\left.{ }^{*}\right)$ Municipality contemplated in SAG.

\section{Discussion}

The evolution of GAGR from 2005 to 2014 in urbanised areas was $0.68 \%$ p.a. in SAG and less than $1.24 \%$ p.a. BSMR and other regions of the world, such as $1.52 \%$ p.a. in Latin America and the Caribbean (LAC), are at a rate of $4.57 \%$ p.a. in sub-Saharan Africa and at a rate of $4.53 \%$ p.a. in Western Asia (IBGE 2010; UN 2016; IBGE 2018). Paradoxically, in informal areas from 2005 to 2018 , GAGR ${ }_{\mathrm{NH}}$ in SAG $74 \mathrm{VN}$ was $5.60 \%$ p.a., while BSMR $525 \mathrm{VN}$ reached $6.07 \%$ p.a., higher than all other areas in LAC $(-0.75 \%$ p.a.), subSaharan Africa (3.12\% p.a.) and Western Asia (3.89\% p.a.) (Young, Fusco 2006; AGEM 2015; UN 2016; Annex A; Annex B). Except for Cubatão municipality, with a negative GAGR $\mathrm{NH}_{\mathrm{NH}}(-7.95 \%$ p.a.), the municipalities of SSEC presented VN with growth types 1 and 2, in non-conforming dwellings and the occupied area or areas of verticalisation and population concentration. Intense urbanisation has significantly altered the physical environment, and the conservation of natural areas near urbanised areas remains to be considered of little importance to the government. Young 2009; Moreira et al. 2017 emphasise that 
the lack of conservation of natural areas in BSMR contributes strongly to environmental degradation and the impacts related to urban activities. On the other hand, in Cubatão, housing policy is based on housing production through partnerships with the state and federal governments. Some projects only include new units, while others have joint urbanisation and housing production actions. In addition to the construction of about 10,000 houses, the projects foresee urban areas occupied by families. The Organic Law of the Municipality of Cubatão establishes in Article 7(2) the municipality's concurrent competence, together with the State of São Paulo and Brazil, to execute housing production programmes. Combining this provision with the relevant chapter on municipal housing policy (Arts. 207 to 211) is the foundation in the local legal system for such sectoral policy and competence that enables the municipality to conclude agreements with other federative entities (Gillan, Charles 2019).

There are significant social impacts of daily releases of in natura effluent of approximately 2,086,000 $\mathrm{m}^{3} \cdot \mathrm{month}^{-1}$, PL of 450 tonnes $\cdot \mathrm{month}^{-1}$, in addition to the inadequate disposal of garbage in water bodies (estuaries, beaches, canals and rivers), as well as the presence of emerging pollutants requiring advanced treatment that is not available from RMBS. Sewage discharges and inadequate waste disposal in the rivers' innermost areas modify estuarine waters' hydrodynamics and cause urban flooding, especially in the summer, when there is a more generous river contribution caused by heavy rains (Berbel et al. 2015). Other locations globally, also densely populated and with a population problem in unstable housing exposed to urban and industrial contaminants, are also affected. For instance, in India, the effects of anthropogenic stress on the Ganges River show increased biochemical oxygen demand (BOD), reduced salinity and $\mathrm{pH}$, as well as the presence of high concentrations of $\mathrm{Hg}$ and $\mathrm{Pb}$, attributed to discharges from manufacturing and industrial processes (Sarkar et al. 2007). Additionally, in India, on the Ganges delta in Bengal, there was evidence of Vibrio cholera concentrations associated with discharges, temperature and salinity of waters in the estuary (Batabyal et al. 2016). In Cameroon, cholera risk factors are associated with slums, poor sanitation and hygiene. There are high cholera risks in
Douala, which demonstrates that the issue goes beyond public health to the point of a humanitarian disaster (Ndah, Ngorah 2015).

The relationship between economic growth and the release of contaminants has been known for some time. Garcia Occhipinti (1986) presented the most relevant aspects for analysing an ocean waste disposal system (OWDS), where he emphasised the tidal regime's interference in the gradient of contaminant concentrations. High concentrations of persistent organic pollutants (POPs) and polycyclic aromatic hydrocarbons (PAHs) are also associated with anthropogenic effects on SSEC (Fontanelle et al. 2019).

The sustainable development goal aims related to the environment, biodiversity and sustainable cities have encountered resource constraints and ineffective government actions (Shibata et al. 2015; WHO 2017; UN-HABITAT 2018). Insufficient urban land tenure regularisation in RMBS cities corroborates VN's 'invisible' growth and exerts negative impacts on transforming the urban environment and public health in SSEC waters and sediments. It is of great complexity to study a natural phenomenon that intensifies due to anthropic activities' interference in coastal environments, especially those that cause eutrophication. The potentially harmful impact portrays this complexity, avoiding an alarmist attitude. We cannot avoid this phenomenon, but we must minimise its causes for maintaining tourism, fishing and improving public health.

Sixty-five percent of the area (Baixada Santista) is occupied by areas of permanent environmental preservation (APPs) with mangroves, restingas and forests in rugged mountains (https:// www.diariodolitoral.com.br/cotidiano/baixada-tem646-do-territory-in-preservation-area/122420/). Permanent environmental preservation is defined by the Brazilian Forest Code (Law No. 12,651 of May 25, 2012) as untouchable areas, where it is not allowed to build, cultivate or economically exploit. For it to exist, it is enough that the geographical condition is met, regardless of the domain of the existing area or vegetation. The limits of the areas of permanent environmental preservation (APPs), which should be strictly monitored, are, in practice, abandoned as a result of the scrapping policy of the inspection bodies (Oliveira et al. 2020). The result is constant invasions, rapidly increasing the vulnerable 
population and causing conflicts between public institutions, where investments by the concessionaires in infrastructure works are prevented by legal uncertainty, resulting from the condition of a permanent preservation area. Therefore, it is necessary to change the current environmental management system so as to allow human activities integrated with the responsibility of maintaining processes, phenomena and riverside resources. In other words, we must encourage the concession of riverside resources within management plans with guidelines and responsibilities to conserve water and the environment.

\section{Conclusion}

The geometric rate of annual growth of the population in non-conforming housing $\left(\mathrm{GAGR}_{\mathrm{NH}}\right)$ is approximately five times higher than that of the compliant population in the Baixada Santista Metropolitan Region (BSMR). It exceeds all world growth rates, even in the poorest regions of Latin America and sub-Saharan and West Africa.

The vulnerable nuclei $(\mathrm{VN})$ growth clusters show that $85 \%$ of the VN result from invasions, reinvasions, densification and verticalisation, while $15 \%$ represent the government's areas' demobilisation actions, without actions to recover degraded areas.

The release of sewage in the Santos and São Vicente Estuarine Complex (SSEC) by the study area group (SAG) exceeds 450 tonnes $\cdot$ month $^{-1}$ and a flow of 2,650,000 $\mathrm{m}^{3} \cdot \mathrm{month}^{-1}$, and the negative impacts from the release and disposal of waste on the banks of water bodies pose risks to public health.

Estuary hydrodynamics do not promote the renewal of SSEC waters and turn its water into a large receptacle for sewage and emerging pollutants. As this is a port region, the contamination of these water bodies has potential risks of contamination and the spreading of diseases worldwide.

A comparison of these historical data clearly shows the escalation of nutrient entry into SSEC and increased concentrations associated with the growth of informal populations in the Santos metropolitan region beyond the limit of the estuarine system's carrying capacity, revealing the enormous pressure on the ecosystem.
The results show accelerated degradation of ecosystems, damage to public and environmental health, and potential risks of spreading disease in SSEC.

The re-urbanisation of the area using economic resources caused by the loss of water must be taken to reduce the risks of ecosystem degradation, damage to health and the spread of diseases.

This study has great potential to solve problems of urbanisation and sanitation in slum areas using resources from the economy generated by non-waste of treated water in irregular distribution. In a global scenario, this proposal could also be used in other regions of irregular housing in Brazil, and even studies of this nature in other parts of the world in less developed countries can lead to similar results and, consequently, solve water contamination problems.

\section{References}

AGEM, 2015. Regional program for the identification and monitoring of disappointed housing areas - PRIMAHD. Online: http://www.agem.sp.gov.br. 2005 (accessed: June 2019).

Balk D., Montgomery M.R., McGranahan G., Kim D., Mara V., Todd M., Buettner T., Dorélien A., 2009. Mapping urban settlements and the risks of climate change in Africa, Asia and South America. In: Guzmán J.M., Martine G., McGranahan G., Schensul D., Tacoli C., (eds), Population dynamics and climate change. United Nations Population Fund (UNFPA), International Institute for Environment and Development (IIED). New York, London: 80-103.

Batabyal P., Mookerjee S., Einsporn M.H., Lara R.J., Paleit A., 2016. Environmental drivers on seasonal abundance of riverine-estuarine $V$. cholerae in the Indian Sundarban mangrove. Ecological indicators 69: 59-65. DOI 10.1016/j. ecolind.2016.04.004.

Berbel G.B., Favaro D.I., Braga E.S., 2015. Impact of harbor, industry and sewage on the phosphorus geochemistry of a subtropical estuary in Brazil. Marine Pollution Bulletin 93(1-2): 44-52. DOI 10.1016/j.marpolbul.2015.02.016.

BRASIL. Resolução CONAMA 357, de 17 de março de 2005 Conselho Nacional de Meio Ambiente. Online: http://www.mma.gov.br/port/conama/res/res05/ res35705.pdf (accessed: June 2018).

Campuzano F.J., Mateus M.D., Leitão P.C., Leitão P.C., Marín V.H., Delgado L.E., Tironi A., Pierini J.O., Sampaio A.F.P., Almeida P., Neves R.J., 2013. Integrated coastal zone management in South America: A look at three contrasting systems. Ocean \& Coastal Management 72: 22-35. DOI 10.1016/j.ocecoaman.2011.08.002.

CEMADEN, 2017. Rainfall index of the state of São Paulo. Online: http://www.cemaden.gov.br (accessed: June 2019).

CETESB, 2011. Quality report of the coastal beaches of the state of São Paulo. Online: http://cetesb.sp.gov.br (accessed: June 2019). 
CETESB, 2017. Quality report of the coastal beaches of the state of São Paulo. Online: http://cetesb.sp.gov.br (accessed: June 2019).

Cutter S.L., Boruff B.J., Shirley W.L., 2003. Social vulnerability to environmental hazards. Social science quarterly 84(2), 242-261. DOI 10.1111/1540-6237.8402002.

Fabiano C., Muniz S., 2010. Vila Gilda stilt: Paths to regularization. Online: http://www.ipea.gov.br/ppp/index. php/PPP/article/view/173 (accessed: June 2019).

Fontanelle F.R., Tanigushi S., Silva J.S., Lourenço R.A., 2019. Environmental quality survey of an industrialized estuary and an Atlantic Forest Biosphere Reserve through a comparative appraisal of organic pollutants. Environmental Pollution 248: 339-348. DOI 10.1016/j.envpol.2019.02.023.

Garcia Occhipinti A., 1986. A conceptual approach to ocean disposal. Water Science and Technology 18(11): 141-158. DOI 10.2166/wst.1986.0150.

Gillam C., Charles A., 2019. Community wellbeing: The impacts of inequality, racism and environment on a Brazilian coastal slum. World Development Perspectives 13: 18-24. DOI 10.1016/j.wdp.2019.02.006.

Harari J., França C.A.S., Marques J., 2007. Aplicações da modelagem numérica da Baía de Santos (SP, Brasil): correntes residuais e dispersão de poluentes. Encontro Internacional De Governança Da Água Na América Latina 1: 1-15.

IBGE, 2010. Demographic census. Online: http://www.ibge. gov.br (accessed: June 2019).

IBGE, 2018. Statistical projection. Online: http:/ / www.ibge. gov.br (accessed: June 2019).

Kron W., 2013. Coasts: The high-risk areas of the world. Natural Hazards 66: 1363-1382. DOI 10.1007/s11069-012$0215-4$.

Leridon H., 2020. World population outlook: Explosion or implosion? Population Societies 1: 1-4. DOI 10.3917/popsoc.573.0001.

Moreira F.D.A., Rampazo N.A.M., Castellano M.S., 2017. Impacts of rainfall and vulnerabilities in the metropolitan region of Baixada Santista, Brazil. International Journal of Safety and Security Engineering 7(2): 169-179.

Ndah A., Ngoran S.D., 2015. Liaising water resources consumption, urban sanitation and cholera epidemics in Douala, Cameroon: A community vulnerability assessment. Online: https://www.researchgate.net/profile/ Suinyuy_Derrick_Ngoran/publication/288181541_Liaising_Water_Resources_Consumption_Urban_Sanitation_and_Cholera_Epidemics_in_Douala_Cameroon_A_Community_Vulnerability_Assessment/ links/567eca8f08aebccc4e05de9a.pdf (accessed: June 2019).

Neumann B., Vafeidis A.T., Zimmermann J., Nicholls R.J., 2015. Future coastal population growth and exposure to sea-level rise and coastal flooding - A global assessment. PLOS One 10(3): e0118571. DOI 10.1371/journal. pone. 0118571.

Oliveira E.F.C., Silva J.A.F., Oliveira Júnior J.F., 2020. Critical analysis of the Brazilian environmental safety system. Revista Do Instituto Brasileiro De Segurança Pública (RIBSP) 3(7): 9-35. DOI 10.36776/ribsp.v3i7.87.

Pereira C.D.S., Maranho L.A., Cortez F.S., Pusceddu F.H., Santos A.R., Ribeiro D.A., Cesar A., Guimarães L.L., 2016.
Occurrence of pharmaceuticals and cocaine in a Brazilian coastal zone. Science of the Total Environment 548: 148-154. DOI 10.1016/j.scitotenv.2016.01.051.

RIPSA. International Health Information Network. Online: http://www.ripsa.org.br/fichasIDB/pdf/ ficha_A.3.pdf. 2018 (accessed: June 2019).

Sampaio A.F.P., 2011. Avaliação da correlação entre parâmetros de qualidade da água e socioeconômicos no Complexo Estuarino de Santos - São Vicente, através de modelagem numérica ambiental. Dissertação de Mestrado, Ciência Ambiental, Universidade de São Paulo, São Paulo. DOI 10.11606/D.90.2011.tde-23112011-105215.

São Paulo, 2010. Paulista vulnerability index. Online: http:// indices-ilp.al.sp.gov.br (accessed: June 2019).

Sarkar S.S., Saha S., Takada H., Bhattacharya A., Mishra P., Bhattacharya P., 2007. Water quality management in the lower stretch of the river Ganges, east coast of India: An approach through environmental education. Journal of Cleaner Production 15(16): 1559-1567. DOI 10.1016/j.jclepro.2006.07.030.

Shibata T., Wilson J.L., Watson L.M., Nikitina I.V., Ansariadi La Ane R., Maidin A., 2015. Life in a landfill slum, children's health, and the millennium development goals. Science of the Total Environment 536: 408-418. DOI 10.1016/j.scitotenv.2015.05.137.

Small C., Nicholls R.J., 2003. A global analysis of human settlement in coastal zones. Journal of Coastal Research 19: 584-599.

SNIS, 2017. National sanitation information system. Online: http:/ / www.snis.gov.br (accessed: June 2019).

UN, 2012. The future we want - Ministry of environment. Online: http://www2.mma.gov.br/port/conama/processos/61AA3835/O-Futuro-que-queremos1.pdf (accessed: June 2019).

UN, 2013. Sustainable development challenges. World Economic and Social Survey. Online: https://data.worldbank.org/ share $/$ widget?end $=2014$ \&indicators $=E N$. POP.SLUM.UR.ZS\&start=2014\&type=shaded $\& v i e w=m-$ ap" width $=^{\prime} 450^{\prime}$ height $={ }^{\prime} 300^{\prime}$ frameBorder $=0^{\prime}$ scrolling="no" ></iframe> (accessed: June 2019).

UN-BR, 2018. Glossary of terms of the sustainable development objective. Online: http://www.br.undp.org/ content/brazil/pt/home/library/ods/glossario-ods-11. html (accessed: June 2019).

UN-HABITAT, 2018. Tracking progress towards inclusive, safe, resilient, and sustainable cities and human settlements. Online: https://unhabitat.org/sdg-11-synthesis-report/ (accessed: June 2019).

Von Sperling M., 2014. Introduction to water quality and sewage treatment, Pampulha, Universidade Federal de Minas Gerais (UFMG), Minas Gerais, Brazil. 2nd ed.

WHO, 2017. Progress on drinking water, sanitation and hygiene: 2017 update and SDG baselines. 1. Water supply - standards. 2. Sanitation - trends. 3. Drinking water supply and distribution.

Young A.F., Fusco W., 2006. Espaços de Vulnerabilidade Sócio-ambiental para a População 10. da Baixada Santista: identificação e análise das áreas críticas. $\mathrm{XV}$ Encontro $\mathrm{Na}$ cional de Estudos Populacionais-desafios e oportunidades do crescimento zero 15: 1-17. Online: https:/ / www.researchgate.net/ publication/274192751(accessed: June 2019). 
Annex A. Territorial and housing growth in VN in the studied area.

\begin{tabular}{|c|c|c|c|c|c|c|c|c|c|}
\hline Id & $\begin{array}{l}\text { UTM } \\
(\mathrm{E} ; \mathrm{S})\end{array}$ & County & $\mathrm{VN}$ & $\begin{array}{c}\text { Area - } 2005 \\
\left(\mathrm{~m}^{2}\right)\end{array}$ & $\begin{array}{l}\text { HD } \\
2005\end{array}$ & $\begin{array}{c}\text { Area - } 2018 \\
\left(\mathrm{~m}^{2}\right)\end{array}$ & $\begin{array}{l}\text { HD } \\
2018\end{array}$ & $\begin{array}{l}\text { GAGR }_{\mathrm{NH}} \\
(\% / \text { a.a })\end{array}$ & $\begin{array}{l}\text { GAGR }_{\mathrm{m}}{ }^{2} \\
(\% / \text { a.a })\end{array}$ \\
\hline 1 & $\begin{array}{c}352,171 ; \\
7,355,944\end{array}$ & Cubatão & Vila Esperança & 655,700 & 2,534 & 827,979 & 1,342 & $-4.77 \%$ & $1.81 \%$ \\
\hline 2 & $\begin{array}{c}354,036 \\
7,356,544\end{array}$ & Cubatão & Costa Muniz & 177,500 & 401 & 58,848 & 0 & $-100.00 \%$ & $-8.14 \%$ \\
\hline 3 & $\begin{array}{c}\text { 357,356; } \\
7,353,247\end{array}$ & Cubatão & V, Pescadores & $2,877,100$ & 1,520 & 282,143 & 1,064 & $-2.71 \%$ & $-16.36 \%$ \\
\hline 4 & \begin{tabular}{|c|}
351,$666 ;$ \\
$7,358,099$
\end{tabular} & Cubatão & $\begin{array}{l}\text { Pinhal do Mi- } \\
\text { randa }\end{array}$ & 289,900 & 1,118 & 178,154 & 204 & $-12.27 \%$ & $-3.68 \%$ \\
\hline 5 & $\begin{array}{r}355,328 \\
7,358,445\end{array}$ & Cubatão & Beira Rio & 0 & 0 & 8,555 & 40 & $1.43 \%$ & $1.43 \%$ \\
\hline 6 & $\begin{array}{l}353,475 ; \\
7357,148\end{array}$ & Cubatão & Vila Noel & 0 & 0 & 36,219 & 161 & $1.43 \%$ & $1.43 \%$ \\
\hline 7 & $\begin{array}{c}354,069 \\
7,352,270\end{array}$ & Cubatão & Ilha Caraguata $\left(^{*}\right)$ & 25,200 & 101 & 23,016 & 124 & $1.59 \%$ & $-0.69 \%$ \\
\hline 8 & $\begin{array}{c}\text { 351,701; } \\
7,354,366\end{array}$ & Cubatão & Vale Novo & 0 & 0 & 33,977 & 70 & $1.43 \%$ & $1.43 \%$ \\
\hline 9 & $\begin{array}{c}371,803 \\
7,347,426\end{array}$ & Guarujá & $\begin{array}{l}\text { Morro da } \\
\text { Cachoeira }\end{array}$ & 47,600 & 113 & 118,224 & 879 & $17.09 \%$ & $7.25 \%$ \\
\hline 10 & $\begin{array}{c}\text { 372,895; } \\
7,348,238 \\
\end{array}$ & Guarujá & $\begin{array}{c}\text { V, Edna/Selma } \\
\left({ }^{*}\right)\end{array}$ & 141,500 & 1,025 & 330,442 & 1,631 & $3.64 \%$ & $6.74 \%$ \\
\hline 11 & $\begin{array}{c}372,663 ; \\
7,347,696\end{array}$ & Guarujá & Vila Zilda $\left(^{*}\right)$ & 152,300 & 692 & 187,999 & 952 & $2.48 \%$ & $1.63 \%$ \\
\hline 12 & $\begin{array}{c}\text { 371,578; } \\
7,347,426 \\
\end{array}$ & Guarujá & Cachoeira $\left(^{*}\right)$ & 333,000 & 2,574 & 354,186 & 2,094 & $-1.58 \%$ & $0.48 \%$ \\
\hline 13 & $\begin{array}{r}367,440 \\
7,345,505\end{array}$ & Guarujá & $\begin{array}{c}\text { S,C,Navegantes } \\
\left({ }^{*}\right)\end{array}$ & 200,000 & 867 & 216,434 & 1,268 & $2.97 \%$ & $0.61 \%$ \\
\hline 14 & $\begin{array}{c}369,025 \\
7,345,200\end{array}$ & Guarujá & V,Ligia $\left(^{*}\right)$ & 88,000 & 746 & 135,823 & 875 & $1.23 \%$ & $3.39 \%$ \\
\hline 15 & $\begin{array}{c}369,541 \\
7,346,461\end{array}$ & Guarujá & Vila Funchal I e II & 0 & 0 & 18,157 & 174 & $1.43 \%$ & $1.43 \%$ \\
\hline 16 & $\begin{array}{r}370,508 \\
7,346,983 \\
\end{array}$ & Guarujá & $\begin{array}{c}\text { Mangue Seco I } \\
\text { e II }\end{array}$ & 54,700 & 220 & 61,668 & 371 & $4.10 \%$ & $0.93 \%$ \\
\hline 17 & $\begin{array}{c}\text { 369,809; } \\
7,344,955\end{array}$ & Guarujá & LAS PALMAS & 28,700 & 51 & 117,179 & 286 & $14.18 \%$ & $11.43 \%$ \\
\hline 18 & $\begin{array}{l}369,250 ; \\
7,347,791 \\
\end{array}$ & Guarujá & $\begin{array}{c}\text { Sitio Conceiçãoz- } \\
\text { inha }\end{array}$ & 251,700 & 1,083 & 216,780 & 2,865 & $7.77 \%$ & $-1.14 \%$ \\
\hline 19 & $\begin{array}{c}\text { 369,150; } \\
7,353,976\end{array}$ & Guarujá & Monte Cabrão & 56,300 & 70 & 36,636 & 74 & $0.43 \%$ & $-3.25 \%$ \\
\hline 20 & $\begin{array}{l}\text { 366,852; } \\
7,354,530\end{array}$ & Guarujá & $\begin{array}{c}\text { Ilha Diana (San- } \\
\text { tos) }\end{array}$ & 18,500 & 54 & 24,593 & 98 & $4.69 \%$ & $2.21 \%$ \\
\hline 21 & $\begin{array}{c}\text { 366,926; } \\
7,351,960\end{array}$ & Guarujá & Santense & 6,600 & 43 & 2,063 & 90 & $5.85 \%$ & $-8.56 \%$ \\
\hline 22 & $\begin{array}{c}366,272 \\
7,345,243\end{array}$ & Guarujá & Praia do Góes & 34,700 & 72 & 34,044 & 255 & $10.22 \%$ & $-0.15 \%$ \\
\hline 23 & $\begin{array}{l}372,238 \\
7347,471 \\
\end{array}$ & Guarujá & M,Engenho $\left(^{*}\right)$ & 200,800 & 724 & 96,717 & 775 & $0.53 \%$ & $-5.46 \%$ \\
\hline 24 & $\begin{array}{c}367,237 \\
7,350,687\end{array}$ & Guarujá & Prainha $\left(^{*}\right)$ & 344,700 & 1,394 & 427,672 & 4,043 & $8.54 \%$ & $1.67 \%$ \\
\hline 25 & $\begin{array}{c}\text { 367,737; } \\
7,350,122\end{array}$ & Guarujá & Marezinha $\left(^{*}\right)$ & 104,800 & 549 & 108,853 & 713 & $2.03 \%$ & $0.29 \%$ \\
\hline 26 & $\begin{array}{c}369,250 \\
7,352,352\end{array}$ & Guarujá & Vargea Gde $\left(^{*}\right)$ & 0 & 0 & 55,748 & 141 & $1.43 \%$ & $1.43 \%$ \\
\hline 27 & $\begin{array}{c}368,724 \\
7,352,046 \\
\end{array}$ & Guarujá & Favela do Caixão & 55,800 & 519 & 49,697 & 1,593 & $9.01 \%$ & $-0.89 \%$ \\
\hline
\end{tabular}




\begin{tabular}{|c|c|c|c|c|c|c|c|c|c|}
\hline Id & $\begin{array}{l}\text { UTM } \\
(\mathrm{E} ; \mathrm{S})\end{array}$ & County & VN & $\begin{array}{c}\text { Area - } 2005 \\
\left(\mathrm{~m}^{2}\right)\end{array}$ & $\begin{array}{l}\text { HD } \\
2005\end{array}$ & $\begin{array}{c}\text { Area - } 2018 \\
\left(\mathrm{~m}^{2}\right)\end{array}$ & $\begin{array}{l}\text { HD } \\
2018\end{array}$ & $\begin{array}{l}\mathrm{GAGR}_{\mathrm{NH}} \\
(\% / \text { a.a })\end{array}$ & $\begin{array}{l}\text { GAGR }_{\mathrm{m}}{ }^{2} \\
(\% / \text { a.a) }\end{array}$ \\
\hline 28 & $\begin{array}{c}369,457 \\
7,352,130\end{array}$ & Guarujá & Santa Madalena & 50,100 & 295 & 19,850 & 69 & $-10.57 \%$ & $-6.87 \%$ \\
\hline 29 & $\begin{array}{c}\text { 369,076; } \\
7,351,376\end{array}$ & Guarujá & Vila do Padre & 14,500 & 112 & 30,851 & 71 & $-3.45 \%$ & $5.98 \%$ \\
\hline 30 & $\begin{array}{c}369,183 \\
7,351,072\end{array}$ & Guarujá & Atlântica & 0 & 0 & 89,573 & 344 & $1.43 \%$ & $1.43 \%$ \\
\hline 31 & $\begin{array}{c}369,411 \\
7,350,801\end{array}$ & Guarujá & Área Verde & 0 & 0 & 64,191 & 757 & $1.43 \%$ & $1.43 \%$ \\
\hline 32 & $\begin{array}{c}369,498 \\
7,350,937\end{array}$ & Guarujá & N,Republica $\left(^{*}\right)$ & 30,400 & 189 & 74,243 & 330 & $4.38 \%$ & $7.11 \%$ \\
\hline 33 & $\begin{array}{c}369,721 \\
7,350,436\end{array}$ & Guarujá & T, Acaraú $\left(^{*}\right)$ & 41,800 & 183 & 114,735 & 362 & $5.39 \%$ & $8.08 \%$ \\
\hline 34 & $\begin{array}{c}369,892 \\
7,350,251\end{array}$ & Guarujá & Chaparral $(*)$ & 87,000 & 519 & 86,634 & 546 & $0.39 \%$ & $-0.03 \%$ \\
\hline 35 & $\begin{array}{c}370,162 ; \\
7,349,928\end{array}$ & Guarujá & República & 0 & 0 & 44,808 & 257 & $1.43 \%$ & $1.43 \%$ \\
\hline 36 & $\begin{array}{c}370,005 \\
7,349,703\end{array}$ & Guarujá & Rubro Negro & 0 & 0 & 15,414 & 80 & $1.43 \%$ & $1.43 \%$ \\
\hline 37 & $\begin{array}{l}372,238 \\
7347,471\end{array}$ & Guarujá & M,Engenho $\left(^{*}\right)$ & 200,800 & 724 & 96,717 & 775 & $0.53 \%$ & $-5.46 \%$ \\
\hline 38 & $\begin{array}{c}\text { 358,191; } \\
7,353,923\end{array}$ & Santos & V, Criadores $\left(^{*}\right)$ & 52,500 & 177 & 77,979 & 178 & $0.04 \%$ & $3.09 \%$ \\
\hline 39 & $\begin{array}{c}358,838 \\
7,351,402\end{array}$ & Santos & V,Gilda $\left(^{*}\right)$ & 242,700 & 1,249 & 302,807 & 2,521 & $5.55 \%$ & $1.72 \%$ \\
\hline 40 & $\begin{array}{c}\text { 361,203; } \\
7,352,804\end{array}$ & Santos & V, Alemoa $\left(^{*}\right)$ & 119,900 & 768 & 105,480 & 559 & $-2.41 \%$ & $-0.98 \%$ \\
\hline 41 & $\begin{array}{c}360,911 \\
7,352,779\end{array}$ & Santos & V, Alemoa $2\left(^{*}\right)$ & 0 & 0 & 95,310 & 468 & $1.43 \%$ & $1.43 \%$ \\
\hline 42 & $\begin{array}{c}362,351 \\
7,352,311\end{array}$ & Santos & $\begin{array}{c}\text { S, Maria - gleba } \\
\text { I e II }\end{array}$ & 186,700 & 459 & 65,966 & 238 & $-4.93 \%$ & $-7.69 \%$ \\
\hline 43 & $\begin{array}{c}359,669 \\
7,352,179\end{array}$ & Santos & Ilheu Baixo $\left(^{*}\right)$ & 0 & 0 & 54,021 & 74 & $1.43 \%$ & $1.43 \%$ \\
\hline 44 & $\begin{array}{c}361,615 \\
7,352,375\end{array}$ & Santos & $\begin{array}{c}\text { Chico de Paula } \\
\left(^{*}\right)\end{array}$ & 11,700 & 61 & 1,496 & 48 & $-1.83 \%$ & $-14.63 \%$ \\
\hline 45 & $\begin{array}{c}361,540 \\
7,352,251\end{array}$ & Santos & Igreja $\left(^{*}\right)$ & 0 & 0 & 9,147 & 92 & $1.43 \%$ & $1.43 \%$ \\
\hline 46 & $\begin{array}{c}361,369 \\
7,351,767\end{array}$ & Santos & $\begin{array}{c}\text { Cam,Part, S,Jorge } \\
\left({ }^{*}\right)\end{array}$ & 0 & 0 & 11,433 & 57 & $1.43 \%$ & $1.43 \%$ \\
\hline 47 & $\begin{array}{c}361,032 ; \\
7,351,226 \\
\end{array}$ & Santos & $\begin{array}{l}\text { Vila Ayrton } \\
\text { Senna }\end{array}$ & 0 & 0 & 10,873 & 71 & $1.43 \%$ & $1.43 \%$ \\
\hline 48 & $\begin{array}{l}\text { 359,203; } \\
7,353,017\end{array}$ & Santos & Jd, Bom Retiro $\left(^{*}\right)$ & 0 & 0 & 68,120 & 65 & $1.43 \%$ & $1.43 \%$ \\
\hline 49 & $\begin{array}{c}359,542 \\
7,352,940\end{array}$ & Santos & Lot, S,Manoel (*) & 0 & 0 & 148,857 & 289 & $1.43 \%$ & $1.43 \%$ \\
\hline 50 & $\begin{array}{c}363,098 \\
7,352,460\end{array}$ & Santos & $\begin{array}{c}\text { Cam, Maria Rosa } \\
\left({ }^{*}\right)\end{array}$ & 0 & 0 & 1,487 & 54 & $1.43 \%$ & $1.43 \%$ \\
\hline 51 & $\begin{array}{c}363,894 \\
7,352,491\end{array}$ & Santos & Pacheco $\left(^{*}\right)$ & 99,100 & 459 & 201,161 & 1,010 & $6.25 \%$ & $5.60 \%$ \\
\hline 52 & $\begin{array}{c}363,119 \\
7,352,625\end{array}$ & Santos & Penha $\left(^{*}\right)$ & 0 & 0 & 1,676 & 63 & $1.43 \%$ & $1.43 \%$ \\
\hline 53 & $\begin{array}{l}362,486 \\
7352,498\end{array}$ & Santos & Pantanal $\left(^{*}\right)$ & 59,100 & 320 & 78,047 & 819 & $7.50 \%$ & $2.16 \%$ \\
\hline 54 & $\begin{array}{c}359,313 \\
7,352,562\end{array}$ & Santos & S,Manoel $\left(^{*}\right)$ & 115,000 & 333 & 81,895 & 669 & $5.51 \%$ & $-2.58 \%$ \\
\hline 55 & $\begin{array}{c}\text { 358,378; } \\
7,351,880\end{array}$ & S,Vicente & Sambaiatuba $\left(^{*}\right)$ & 336,500 & 810 & 319,237 & 4,050 & $13.18 \%$ & $-0.40 \%$ \\
\hline
\end{tabular}




\begin{tabular}{|c|c|c|c|c|c|c|c|c|c|}
\hline Id & $\begin{array}{l}\text { UTM } \\
(\mathrm{E} ; \mathrm{S})\end{array}$ & County & $\mathrm{VN}$ & $\begin{array}{c}\text { Area - } 2005 \\
\left(\mathrm{~m}^{2}\right)\end{array}$ & $\begin{array}{l}\text { HD } \\
2005\end{array}$ & $\begin{array}{c}\text { Area - } 2018 \\
\left(\mathrm{~m}^{2}\right)\end{array}$ & $\begin{array}{l}\text { HD } \\
2018\end{array}$ & $\begin{array}{l}\mathrm{GAGR}_{\mathrm{NH}} \\
(\% / \mathrm{a} . \mathrm{a})\end{array}$ & $\begin{array}{l}\mathrm{GAGR}_{\mathrm{m}}{ }^{2} \\
(\% / \mathrm{a} . \mathrm{a})\end{array}$ \\
\hline 56 & $\begin{array}{c}348,685 \\
7,345,198\end{array}$ & S,Vicente & Fazendinha $\left(^{*}\right)$ & 0 & 0 & 843,962 & 2,947 & $1.43 \%$ & $1.43 \%$ \\
\hline 57 & \begin{tabular}{|c|}
357,551 \\
$7,350,217$
\end{tabular} & S,Vicente & Começa (b) & 0 & 0 & 15,689 & 802 & $1.43 \%$ & $1.43 \%$ \\
\hline 58 & \begin{tabular}{|c|}
356,468 \\
$7,347,982$
\end{tabular} & S,Vicente & México $70\left(^{*}\right)$ & 625,400 & 3,216 & 737,058 & 4,795 & $3.12 \%$ & $1.27 \%$ \\
\hline 59 & \begin{tabular}{|c|}
351,905 \\
$7,347,424$
\end{tabular} & S,Vicente & $\begin{array}{l}\text { Quarentenário } \\
\text { Publ, }\end{array}$ & 722,500 & 1,522 & 690,601 & 1,178 & $-1.95 \%$ & $-0.35 \%$ \\
\hline 60 & \begin{tabular}{|c|}
351,$149 ;$ \\
$7,346,496$ \\
\end{tabular} & S,Vicente & Rio Negro $(*)$ & 482,900 & 272 & 682,454 & 1,525 & $14.18 \%$ & $2.70 \%$ \\
\hline 61 & $\begin{array}{c}352,667 \\
7,349,766\end{array}$ & S,Vicente & Vila Feliz & 23,100 & 202 & 59,145 & 1,293 & $15.35 \%$ & $7.50 \%$ \\
\hline 62 & \begin{tabular}{|c|}
359,256 \\
$7,350,595$ \\
\end{tabular} & S,Vicente & Miau & 0 & 0 & 28,949 & 598 & $1.43 \%$ & $1.43 \%$ \\
\hline 63 & \begin{tabular}{|c|}
358,756 \\
$7,350,726$
\end{tabular} & S,Vicente & Charme (a) & 0 & 0 & 63,838 & 2,124 & $1.43 \%$ & $1.43 \%$ \\
\hline 64 & $\begin{array}{c}357,122 \\
7,351,254\end{array}$ & S,Vicente & Dq Caixeta $(*)$ & 181,500 & 814 & 158,896 & 2,624 & $9.42 \%$ & $-1.02 \%$ \\
\hline 65 & \begin{tabular}{|c|}
357,004 \\
$7,351,005$
\end{tabular} & S,Vicente & Dique do Fátima & 24,000 & 149 & 29,756 & 1,690 & $20.54 \%$ & $1.67 \%$ \\
\hline 66 & \begin{tabular}{|c|}
357,182 \\
$7,349,308$
\end{tabular} & S,Vicente & Fepasa $\left(^{*}\right)$ & 24,400 & 164 & 25,128 & 1,091 & $15.69 \%$ & $0.23 \%$ \\
\hline 67 & \begin{tabular}{|c|}
352,454 \\
$7,350,385$
\end{tabular} & S,Vicente & $\begin{array}{c}\text { V,Nova Mariana } \\
\left({ }^{*}\right)\end{array}$ & 36,200 & 94 & 88,225 & 635 & $15.83 \%$ & $7.09 \%$ \\
\hline 68 & \begin{tabular}{|c|}
358,276 \\
$7,350,041$ \\
\end{tabular} & S,Vicente & $\begin{array}{c}\text { Sá Catarina } \\
\text { Moraes }\end{array}$ & 112,200 & 680 & 122,538 & 1,261 & $4.87 \%$ & $0.68 \%$ \\
\hline 69 & \begin{tabular}{|c|}
358,441 \\
$7,346,206$
\end{tabular} & S,Vicente & Japuí & 0 & 0 & 49,500 & 411 & $1.43 \%$ & $1.43 \%$ \\
\hline 70 & \begin{tabular}{|c|}
358,031 \\
$7,349,821$
\end{tabular} & S,Vicente & V,S,Bernardo $\left(^{*}\right)$ & 0 & 0 & 18,330 & 339 & $1.43 \%$ & $1.43 \%$ \\
\hline 71 & $\begin{array}{c}358,378 \\
7,351,880\end{array}$ & S,Vicente & Rio d'Avó & 61,200 & 340 & 184,499 & 945 & $8.18 \%$ & $8.86 \%$ \\
\hline 72 & \begin{tabular}{|c|}
360,661 \\
$7,349,014$
\end{tabular} & S,Vicente & $\begin{array}{c}\text { Carrefour (Hor- } \\
\text { to) }\end{array}$ & 0 & 0 & 8,337 & 116 & $1.43 \%$ & $1.43 \%$ \\
\hline 73 & \begin{tabular}{|c|}
360,991 \\
$7,349,339$ \\
\end{tabular} & S, Vicente & Bananal (Horto) & 0 & 0 & 15,178 & 251 & $1.43 \%$ & $1.43 \%$ \\
\hline 74 & \begin{tabular}{|c|}
350,670 \\
$7,347,240$ \\
\end{tabular} & S,Vicente & Jd, Rio B & 0 & 0 & 70 & 367 & $1.43 \%$ & $1.43 \%$ \\
\hline \multicolumn{4}{|c|}{ Total - Study area } & $9,885,500$ & 29,857 & $10,144,527$ & 61,385 & $5.70 \%$ & $0.20 \%$ \\
\hline \multicolumn{4}{|c|}{ RMBS } & & 54,343 & & 116,941 & $6.59 \%$ & \\
\hline
\end{tabular}

GAGR - geometric annual growth rate; $\mathrm{GAGR}_{\mathrm{NH}}$ - geometric rate of annual growth of the population in non-conforming housing; HD - human dwellings; VN - vulnerable nuclei.

Source: AGEM 2005; SABESP 2018, adapted by the author, 2018.

Note: $\left(^{*}\right)$ VN grouped by two or more occupied areas. 


\section{Annex B: Irregular Housing Count in RMBS}

Division of Loss Control of SABESP in 2008 performs irregular area mapping with the help of a drone.

The RMBS has highlighted activities developed in the nine municipalities that seek to reduce the lost water index and loss control in the Business Unit, contributing to its revenue increase. One of the jobs that we highlight in the opportunity is the strong performance of the Baixada Santista Loss Control Division (RSOP) in $\mathrm{VN}$, which are occupied without land regularisation, supporting the recovery of the volume of social use - that is, unbilled consumption.

The unit innovated in the mapping of common areas where water theft is a chronic issue with the help of a drone (operated equipment with a camera attached), and it is possible to photograph 599 irregular areas throughout the Metropolitan Region of Santos-RMBS, from above; this area includes 116,941 irregular dwellings according to a survey conducted from April to December 2018.

Using drones in the locations considered to be at risk due to violence facilitates community growth monitoring while preserving its employees' integrity.

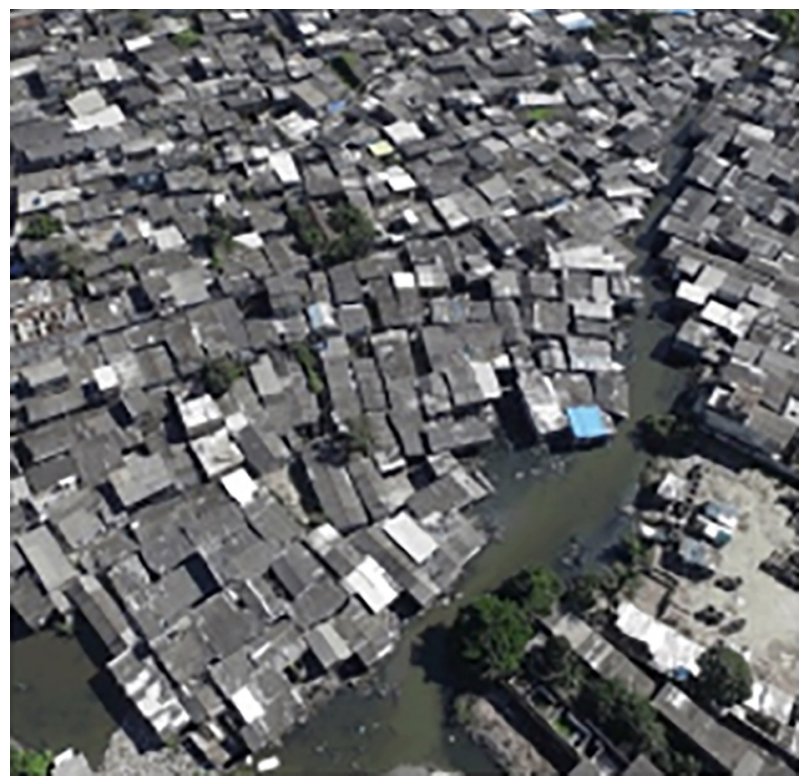

\begin{tabular}{|l|c|c|c|}
\hline \multicolumn{1}{|c|}{ City } & VN (qty) & $\begin{array}{c}\text { Number of ir- } \\
\text { regular dwell- } \\
\text { ings } \text { (qty) }\end{array}$ & Examples \\
\hline Bertioga & 46 & 8,525 & Boraceia \\
\hline Cubatão & 8 & 2,935 & $\begin{array}{c}\text { Vila Esper- } \\
\text { ança }\end{array}$ \\
\hline Guarujá & 73 & 39,345 & Cachoeira \\
\hline Itanhaém & 29 & 4,985 & Iemanjá \\
\hline Mongaguá & 27 & 2,910 & $\begin{array}{c}\text { Cachoeira V. } \\
\text { São Paulo }\end{array}$ \\
\hline Peruibe & 7 & 658 & $\begin{array}{c}\text { Recreio } \\
\text { Santista }\end{array}$ \\
\hline $\begin{array}{l}\text { Praia } \\
\text { Grande }\end{array}$ & 53 & 12,772 & $\begin{array}{c}\text { Samambaia } \\
\text { Santos }\end{array}$ \\
\hline tenements & 30 & 29,079 & $\begin{array}{c}\text { Dq.Vila Gil- } \\
\text { da, Pantanal }\end{array}$ \\
\hline São Vicente & 306 & 116,941 & \\
\hline RMBS & 599 & 15,732 & \\
\hline
\end{tabular}

VN - vulnerable nuclei. *Number of irregular dwellings $=$ Total number of dwellings in irregular areas - number of active water connections in irregular areas. 